\title{
Подтверждение порядка элюирования продуктов взаимодействия гентамицина с ортофталевым альдегидом по скорости реакции дериватизации
}

\author{
(C) 2021 Голубицкий Г.Б. ${ }^{1}$, Шохин И.Е. ${ }^{1}$, Миненкова И.В. ${ }^{2}$, Буряк А.К. ${ }^{2}$ \\ ${ }^{1}$ ООО «Центр фармачевтической аналитики», Москва \\ ${ }^{2}$ Институт физической химии и электрохимии им. А.Н. Фрумкина» $P A H$, Москва
}

Поступила в редакцию 19.11.2020 г.

DOI: $10.17308 /$ sorpchrom.2021.21/3350

Целью работы является подтверждение порядка элюирования продуктов взаимодействия компонентов гентамицина с ортофталиевым альдегидом (ОФА) по скорости реакции дериватизации в присутствии ДМСО, а также оценка влияния содержания ДМСО в смеси на скорость реакции.

Гентамицин - антибиотик широкого спектра действия, широко используемый в медицине. Структурные компоненты гентамицина различаются количеством и положением метильных радикалов, замещающих атомы водорода одной из аминогрупп.

Оптимизировано разделение продуктов взаимодействия компонентов гентамицина с ОФА в обращенно-фазовой системе с использованием смеси ацетонитрил - вода - хлорная кислота - аммиак в качестве подвижной фазы. При оптимизации условий разделения производных гентамицина и ОФА было показано, что разделение пиков улучшалось при переходе $\mathrm{pH}$ солевой составляющей подвижной фазы от 2.5 к 6.1. Кроме этого, был подобран профиль градиента, обеспечивающий минимальную продолжительность анализа при полном разделении компонентов. Изучено влияние содержания ДМСО на скорость дериватизации и стабильность продуктов реакции. Показано, что содержание органического растворителя в диапазоне $20 \div 30$ об.\% обеспечивает максимальную стабильность образующихся продуктов. Установлено, что скорость реакции дериватизации максимальная для продукта, элюирующегося первым, минимальна - для последнего из них и имеет промежуточную величину для компонентов с промежуточными временами удерживания. Скорость реакции зависит от количества метильных заместителей аминогруппы и их положения, что оказывает стерическое влияние на взаимодействие компонентов с реагентом. Гидрофобность разделяемых продуктов также зависит от этих факторов, что объясняет корреляцию порядка элюирования со скоростью реакции дериватизации. Полученные закономерности могут быть использованы при разработке методик анализа органических веществ и их смесей методом ВЭЖХ с предколоночной дериватизацией.

Ключевые слова: гентамицин, компоненты лекарственного средства, ортофталевый альдегид, скорость реакции дериватизации, порядок элюирования.

\section{Введение}

Гентамицин (ГМ) - антибиотик широкого спектра действия, широко используемый в медицине. Методы анализа ГМ и его аналогов описаны в фармакопеях [1-3], монографии [4] и научной периодике [5-12]. Для количественного определения ГМ в Европейской фармакопее [1] и фармакопее США [2] предусмотрен микробиологический метод, а

для определения компонентного состава - метод ВЭЖХ.

ГМ - многокомпонентное лекарственное средство, содержащее пять основных составляющих. Структуры компонентов ГМ различаются количеством и положением метильных радикалов, замещающих атомы водорода одной из аминогрупп (далее по тексту АГ)(рис. 1). 


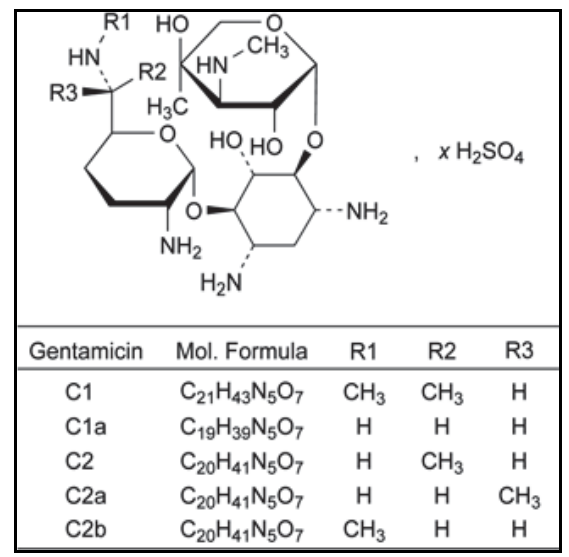

Рис. 1. Химическая структура гентамицина

Fig. 1. Chemical structure of gentamicin

Эти факторы влияют на гидрофобность и форму молекул, что определяет их хроматографические свойства и позволяет разделять в обращенно-фазовом режиме. Компоненты ГМ практически не поглощают в УФ-диапазоне спектра, поэтому для их детектирования необходимы альтернативные методы, например, амперометрический [1], либо дериватизация с получением светопоглощающих производных.

В качестве реагентов для дериватизации ГМ используют о-фталевый альдегид [2-6], флуорескамин [7], бензолсульфонилхлорид [8], дансил хлорид $[9,10]$, тринитробензолсульфокислоту [11], 1-фтор-2,4-динитробензол [12].

Одним из наиболее широко используемых дериватизирующих реагентов для количественного определения первичных аминов является о-фталевый альдегид (ОФА). В присутствии меркаптоэтанола или других тиольных соединений реакция протекает по следующей схеме [4] (рис. 2):

Скорость процесса достаточно велика уже при комнатной температуре и продукт реакции образуется в течение нескольких минут [3, 4]. Мягкие условия получения производных, их стабильность, дешевизна реактивов, а также наличие в продаже готовых к применению смесей в удобной упаковке позволяют считать ОФА одним из лучших реактивов для дериватизации ГМ.

По методике Европейской Фармакопеи 8 издания [1] компонентный состав ГМ определяют при помощи ВЭЖХ без дериватизации с амперометрическим детектированием с использованием в качестве подвижной фазы (ПФ) водного раствора $\mathrm{CH}_{3} \mathrm{CN} \quad\left(1.5\right.$ об.\%), $\mathrm{CF}_{3} \mathrm{COOH}$ $(0.7$ об.\%) и пентафтормасляной кислоты $(0.0250$ об. \%), $\mathrm{pH}$ которого доведен до 2.6 добавлением раствора $\mathrm{NaOH}$ [1]. Порядок элюирования пиков компонентов ГМ следующий: C1a, C2, C2b, C2a, C1. Этот порядок определяется двумя основными факторами - гидрофобностью разделяемых компонентов и их пространственной конфигурацией, определяющей площадь контакта молекул с поверхностью сорбента. Действительно, гидрофобность компонентов возрастает в последовательности C1a (отсутствуют метильные заместители в АГ) - C2, С2a и $\mathrm{C} 2 \mathrm{~b}$ (по одному метильному заместителю) - С1 (два заместителя) в АГ, что<smiles>[2H]n1cc2ccc(CCOCCO)cc2c1SCCOCCO</smiles>

Рис. 2. Схема реакции аминопроизводных с ортофталевым альдегидом Fig. 2. Scheme of the reaction of amino derivatives with ortho-phthalic aldehyde 
соответствует порядку элюирования.

В фармакопее США 36 издания (USP36 - NF31) описана методика определения компонентного состава ГМ с ОФА, согласно которой элюирование проводят в изократическом режиме с ПФ, содержащей $0.5 \%$ гептансульфоната натрия в смеси (70:25:5) метанол-водаледяная уксусная кислота. Дериватизацию ГМ проводят раствором ОФА, содержащим 5 об.\% метанола, 2 об.\% тиогликолевой кислоты в $0.4 \mathrm{M}$ растворе борной кислоты (pH 10.4 добавлением 8н. раствора гидроксида калия). Реакцию ГМ с ОФА проводят в течение 15 мин при $60^{\circ} \mathrm{C}$ в растворе, содержащем 60 об.\% изопропиловый спирт (ИПС). На хроматограмме регистрируют пики четырех компонентов ГМ в следующей последовательности: C1, C1a, C2a и С2 [1]. Отличие порядка элюирования пиков в этой методике по сравнению с методикой European Pharmacopoeia (ЕР) объясняется влиянием ион-парного реагента гептансульфоната натрия. Пентафтормасляная кислота, используемая в составе ПФ в методике ЕР, также является ион-парным реагентом по отношению к соединениям, содержащим аминогруппы, но ее влияние слабее, чем действие алкилсульфонатов.

Можно предположить, что с ПФ состава ацетонитрил - вода $-0.5 \%$ хлорная кислота (рН 6.1), используемой в данной работе, порядок компонентов будет таким же, как в ЕР: оба варианта используют обращенно-фазовый режим, а ПФ содержит слабый ион-парный реагент перхлорат или пентафторацетат. Однако, составы и рН ПФ в этих методиках различны. Кроме того, в настоящей работе разделяли не чистые компоненты ГМ, как в ЕР, а их производные с ОФА, поэтому гарантировать идентичность порядка элюирования компонентов ГМ в двух методиках без дополнительной экспериментальной проверки нельзя.

Было сделано предположение, что скорость реакции с ОФА зависит от структуры компонентов ГМ, а именно - окружения АГ. Быстрее всего должна идти реакция с компонентом C1a, поскольку в данном случае в АГ отсутствуют метильные заместители и, как следствие, минимальны стерические затруднения при сближении молекул реагирующих веществ в растворе. По аналогичным соображениям минимальной должна быть скорость реакции дериватизации максимально замещенного компонента $\mathrm{C} 1$, а для реакции ОФА с компонентами $\mathrm{C} 1$ и $\mathrm{C} 2 \mathrm{a}$ и $\mathrm{C} 2 \mathrm{~b}$ можно предполагать промежуточную по величине скорость.

Цель работы - подтверждение порядка элюирования продуктов взаимодействия компонентов ГМ с ОФА по скорости реакции дериватизации в присутствии ДМСО, а также оценка влияния содержания ДМСО в смеси на скорость реакции.

Аналогично методике The United States Pharmacopoeia (USP), реакцию проводили в водно-органическом растворе. Поскольку новую методику разрабатывали для анализа препарата на основе гранул полилактид-гликолида, вместо ИПСа использовали более сильный растворитель - ДМСО.

\section{Экспериментальная часть}

Работу проводили на жидкостном хроматографе Prominence LC-20 с автоматическим дозатором SIL-20AC и диодно-матричным детектором SPD-M20A (Shimadzu), a также pH-метр Seven Compact S20 с комбинированным стеклянным электродом (Mettler Toledo).

В работе использовали готовый реактив производства Agilent Technologies Sigma Aldrich в виде $1 \mathrm{~cm}^{3}$ раствора в боратном буфере в ампулах, содержащий $10 \mathrm{мг} / \mathrm{cm}^{3}$ (ОФА), 3-меркаптопропионовую кислоту в качестве стабилизатора продукта реакции. Анализ проводили с использованием хроматографической колонки $4.6 \times 100$ Cortecs $\mathrm{C} 18$ 2.7 мкм. (Waters). Анализ вели в градиентном режиме элюирования с изменением состава ПФ: от 20 до 65 об.\% 


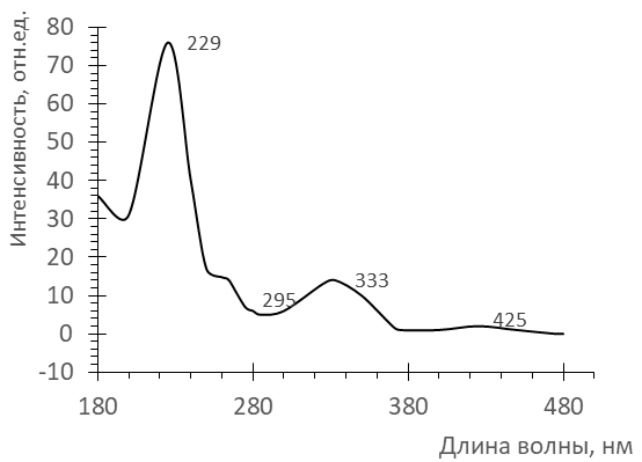

Рис. 3. Спектр поглощения продукта взаимодействия ГМ с ОФА

Fig. 3. Absorption spectrum of the product of interaction of GM with OPA

$\mathrm{CH}_{3} \mathrm{CN}$ за 35 мин $-0.5 \% \mathrm{HClO}_{4}$ (добавление $\mathrm{NH}_{3}$ до $\mathrm{pH}$ 6.1) при скорости потока ПФ $1.0 \mathrm{~cm}^{3} /$ мин. Объем инжектируемой пробы составлял 5 мкл, длина волны детектирования 330 нм, температура колонки и отделения образцов $40^{\circ} \mathrm{C}$.

Анализируемые растворы готовили в градуированных пробирках с притертой пробкой вместимостью $10 \mathrm{~cm}^{3}$. В пробирку помещали $5.0 \mathrm{~cm}^{3}$ водного раствора ГМ с концентрацией около $0.2 \mathrm{мг} / \mathrm{cm}^{3}$, необходимое количество ДМСО и перемешивали полученный раствор. Добавляли 100 мкл реактива ОФА и перемешивали раствор. Добавляли воду до $10 \mathrm{~cm}^{3}$, перемешивали и немедленно переносили часть раствора в виалу хрома- тографа для анализа. Для подтверждения получаемых результатов каждый раствор готовили и анализировали трижды.

\section{Обсуждение результатов}

Детектирование вели при длине волны 330 нм, близкой к длинноволновому максимуму поглощения продукта взаимодействия ГМ с ОФА (рис. 3).

Для разделения использовали ПФ, содержащую ацетонитрил, воду, хлорную кислоту и аммиак. Ранее было показано, что ПФ этого состава обладает высокой прозрачностью в УФ-диапазоне спектра поглощения, обеспечивает эффективное разделение органических веществ различной природы и способствует продле-

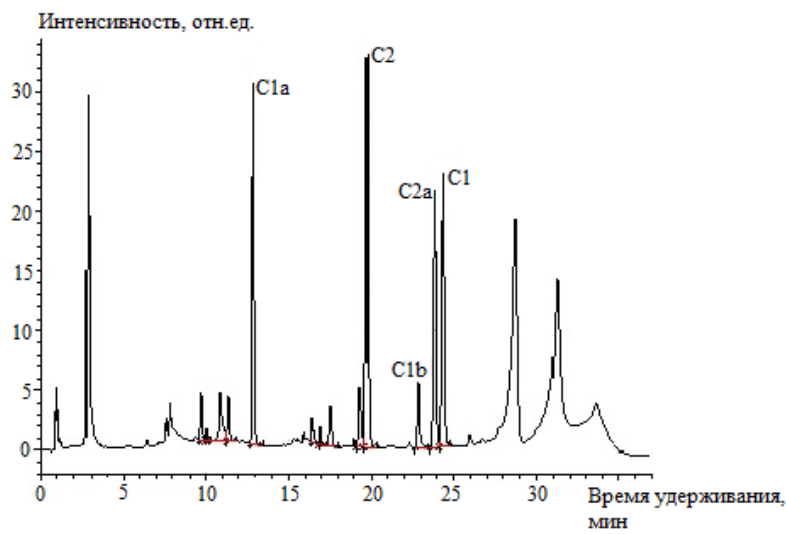

Рис. 4. Хроматограмма раствора ГМ 122 мкг $/ \mathrm{cm}^{3}$ в 30 об.\% ДМСО с добавлением реагента ОФА. Колонка 4.6×100 Cortecs C18 2.7 мкм. ПФ: от 20 до 65 об.\% $\mathrm{CH}_{3} \mathrm{CN}$ за 35 мин $-0.5 \% \mathrm{HClO}_{4}$ (добавление $\mathrm{NH}_{3}$ до $\mathrm{pH} 6.15$ ), скорость потока ПФ $1.0 \mathrm{~cm}^{3} /$ мин, объем инжектируемой пробы 5 мкл. Длина волны детектирования 330 нм. Температура колонки и отделения образцов $40^{\circ} \mathrm{C}$

Fig. 4. Chromatogram of a GM solution of $122 \mu \mathrm{g} / \mathrm{ml}$ in 30 vol. \% DMSO with the addition of OPA reagent. Column $4.6 \times 100$ Cortecs C18 $2.7 \mu \mathrm{m}$. Mobile phase: 20 to 65 vol. $\% \mathrm{CH}_{3} \mathrm{CN}$ for $35 \mathrm{~min}-0.5 \% \mathrm{HClO}_{4}$ (addition of $\mathrm{NH}_{3}$ to $\mathrm{pH} 6.15$ ), mobile phase flow rate $1.0 \mathrm{sm}^{3} / \mathrm{min}$, injected sample volume $5 \mu \mathrm{L}$. The detection wavelength is $330 \mathrm{~nm}$. Column and sample separation temnerature $40^{\circ} \mathrm{C}$ 

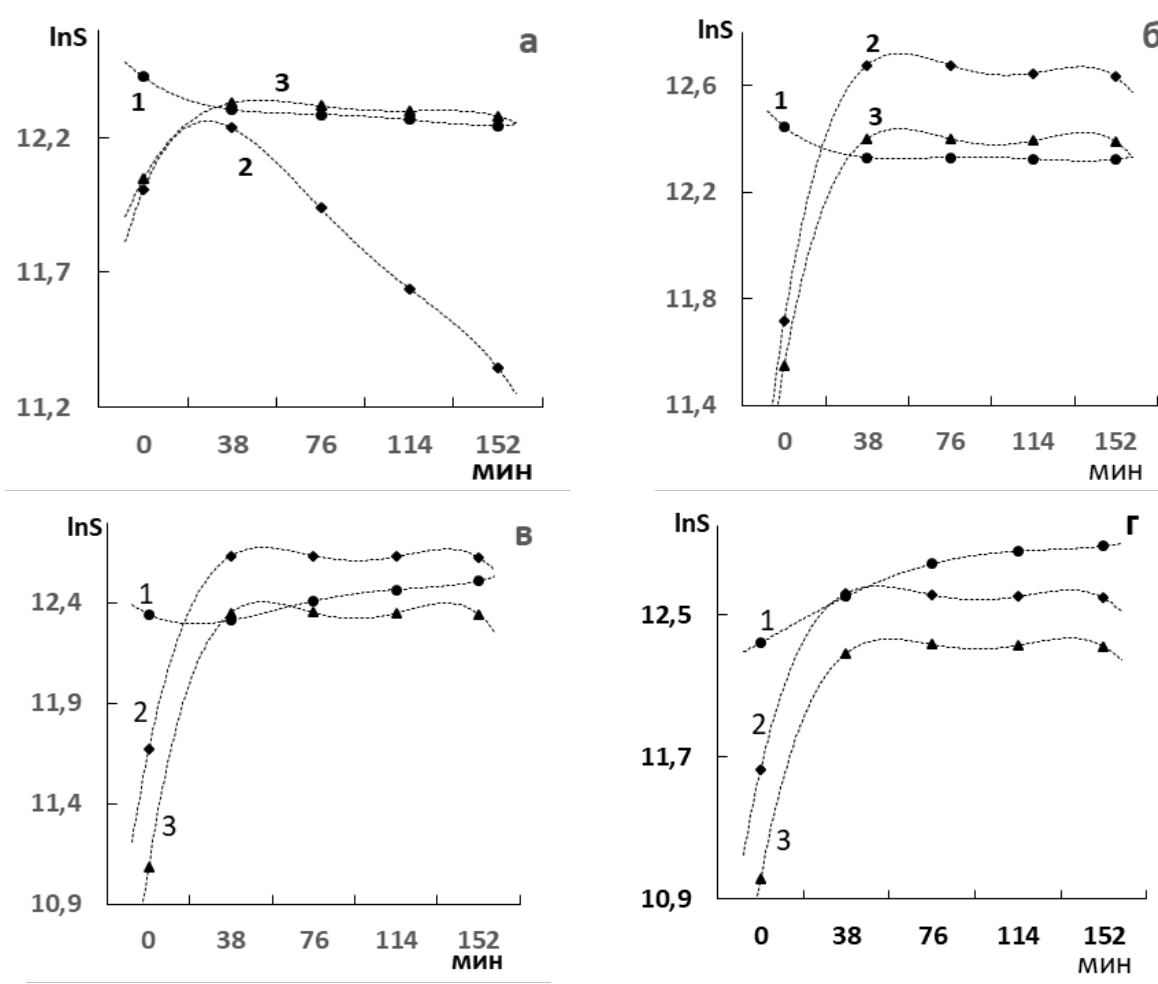

Рис. 5. Зависимость натуральных логарифмов площадей пиков от времени реакции образования продуктов взаимодействия компонентов ГМ (1-C1a, 2-C2; 3 - С1) с ОФА при различном содержании ДМСО в растворах, об. \%: а - 0; б - 30; в, г - 50. Температура растворов $25^{\circ} \mathrm{C}$ (а-в), $40^{\circ} \mathrm{C}$ (г).

Fig. 5. Dependence of the natural logarithms of the peak areas on the reaction time of the formation of the products of the interaction of GM components $(1-\mathrm{C} 1 \mathrm{a}, 2-\mathrm{C} 2 ; 3-\mathrm{C} 1)$ with OPA at different DMSO content in solutions, vol. \%: $\mathrm{a}-0 ; \mathrm{b}-30 ; \mathrm{v}, \mathrm{g}-50$. The temperature of the solutions is $25^{\circ} \mathrm{C}(\mathrm{a}-\mathrm{g}), 40^{\circ} \mathrm{C}(\mathrm{d})$.

нию срока службы хроматографического оборудования и колонок $[13,14]$. При оптимизации условий разделения производных ГМ-ОФА было показано, что разделение пиков улучшалось при переходе $\mathrm{pH}$ солевой составляющей ПФ от 2.5 к 6.1. Кроме этого, был подобран профиль градиента, обеспечивающий минимальную продолжительность анализа при полном разделении компонентов (рис. 4).

Эта методика разделения осуществляется почти в два раза быстрее, чем в ЕР и более практична, чем в USP благодаря отсутствию в ПФ алкилсульфоната.

Кинетические кривые образования производных трех компонентов ГМ с ОФА при различном содержании ДМСО в растворах представлены на рис. 5, при содержании ДМСО 30 об.\% в табл. 1.
При любой концентрации ДМСО в реакционной смеси площадь пика продукта реакции $\mathrm{C} 1$ на первой хроматограмме ( $\mathrm{t}=0$ мин) максимальна, С2 - минимальна, C1a и C2a - имеют промежуточное значение. При отсутствии органического растворителя в смеси продукт С2 нестабилен - через 40 мин после начала реакции его концентрация начинает снижаться. При содержании ДМСО, равном 40 об.\% и повышенной температуре $\left(40^{\circ} \mathrm{C}\right)$ для продукта $\mathrm{C} 1 \mathrm{a}$ значение площади пика на хроматограмме постепенно возрастает в течение четырех часов протекания процесса.

Таким образом, эти результаты подтверждают теоретические предположения о максимальной реакционной способности по отношению к ОФА компонента C1a, минимальной - компонента $\mathrm{C} 1$ и промежуточной - C2 и С2a. Для 
Таблица 1. Значение натуральных логарифмов площадей пиков (площадь пика в мкВ ×c) на хроматограмме образования продуктов взаимодействия компонентов ГМ с ОФМ при концентрации ДМСО 30 об.\%. Температура растворов $25^{\circ} \mathrm{C}$

Table 1. The value of the natural logarithms of the peak areas (peak area in $\mu \mathrm{V} \times \mathrm{s}$ ) on the chromatogram of the formation of the products of the interaction of GM components with OPM at a DMSO concentration of $30 \mathrm{vol} \%$. The temperature of the solutions is $25^{\circ} \mathrm{C}$

\begin{tabular}{|c|c|c|c|c|c|}
\hline \multirow{2}{*}{ Компонент } & \multicolumn{5}{|c|}{ Время, мин } \\
\cline { 2 - 6 } & 0.0 & 38 & 76 & 114 & 152 \\
\hline $\mathrm{C} 1 \mathrm{a}$ & 12.45 & 12.33 & 12.33 & 12.33 & 12.32 \\
\hline $\mathrm{C} 2$ & 11.72 & 12.68 & 12.68 & 12.65 & 12.63 \\
\hline $\mathrm{C} 2 \mathrm{a}$ & 11.74 & 12.32 & 12.32 & 12.31 & 12.31 \\
\hline $\mathrm{C} 1$ & 11.55 & 12.40 & 12.40 & 12.39 & 12.39 \\
\hline
\end{tabular}

компонента С2b измерения не проводили в связи с относительно малой площадью пика. Принципиальное влияние отсутствие данной информации на общие выводы не оказывает.

Оптимальная концентрация ДМСО в реакционной смеси, обеспечивающая стабильность площадей продуктов реакции - 30 об.\%. Нецелесообразно проводить процесс при повышенной температуре - это снижает стабильность результатов во времени.

\section{Заключение}

Порядок удерживания продуктов взаимодействия компонентов ГМ с ОФА зависит от числа метильных заместителей аминогруппы, влияющего на гидрофобность и пространственную структуру

\section{Список литературы}

1. European Pharmacopoeia. 8th edition (EP 8.0). 2013. Vol. 2, pp. 2326-2328.

2. The United States Pharmacopoeia. The National Formulary (USP36 - NF31). 2013. Vol. 2, pp. 3720-3721.

3. European Pharmacopoeia Reference Standard. Information Leaflet. Gentamicin for Peak Identification Crs batch 3. 2017. 3 p.

4. Moldoveanu S., David V. // J. Chromatography Library. 2002. Vol. 65. pp. 341-401.

5. Abdulsalam I. Al-Amoud, Brian J. Clark, Henry Chrystyn // J. Chromatogr. B. 2002. Vol. 769. pp. 89-95.

6. Cabanes A., Cajal Y., Haro I., Garcia Anton J.M. et al. // J. Liq. Chromatogr. 1991. Vol. 14. No 10. pp. 1989-2010. молекул. От пространственной структуры молекул компонентов ГМ зависит доступность активных центров для реагента, что определяет скорость дериватизации. В результате, скорость реакции дериватизации связана с гидрофобностью молекул компонентов ГМ и их пространственной структурой и, как следствие, коррелирует с порядком их элюирования в обращено-фазовой системе. Указанная закономерность может быть использована для определения порядка удерживания компонентов при разработке методик анализа органических веществ с использованием обращено-фазовой ВЭЖХ.

7. Walker S.E., Coates P-E. // J. Chromatogr. 1981. Vol. 223.pp. 131-138.

8. Larsen N-E., Marinelli E. // J. Chromatogr. B. 1980. Vol. 221. pp. 182-187.

9. Win L. Chiou Roger L. // Clin. Chem, 1978. Vol. 24. No 10. pp.1846-1847.

10. ГОСТ 31789-2012. Рыба, морские беспозвоночные и продукты их переработки. Количественное определение биогенных аминов методом высокоэффективной хроматографии. М. Стандартинформ. 2014. 11 с.

11. Gyarmati B., Hegyesi N., Pukánszky B., Szilágyi A. // Express Polymer Letters. 2015. Vol. 9. No 2. pp 154-164.

12. Barends D. M., Zwaan C. L., Hulshoff A. // J. Chromatogr. B. 1981. Vol. 222. pp. 316323.

13. Голубицкий Г.Б., Владимирова Е.В., Островский К.П., Гельперина С.Э. // Сорб- 
ционные и хроматографические прочессы, 2017. Т. 17. № 5, С. 772-780.

14. Голубицкий Г.Б., Островский К.П., Гельперина С.Э. // Сорбционные и хромато- графические проиессы. 2018. Т. 18. № 4. С. 543-553.

\title{
Confirmation of the order of elution of the products of the interaction of gentamicin with ortho-phthalic aldehyde by the rate of the derivatisation reaction
}

\author{
(C) 2021 Golubitsky G.B. ${ }^{1}$, Shokhin I.E. ${ }^{1}$, Minenkova I.V. ${ }^{2}$, Buryak A.K. ${ }^{2}$ \\ ${ }^{1}$ OOO Center of Pharmaceutical Analytics, Moscow, Russian Federation \\ ${ }^{2}$ Frumkin Institute of Physical Chemistry and Electrochemistry of the Russian Academy of Sciences, Moscow, \\ Russian Federation
}

The aim of this study was the confirmation of the order of elution of the products of interaction of the components of gentamicin with ortho-phthalic aldehyde (OPA) according to the rate of the derivatisation reaction in the presence of DMSO, as well as to assess the effect of the content of DMSO in the mixture on the reaction rate.

Gentamicin is a broad-spectrum antibiotic widely used in medicine. The structural components of gentamicin differ in the number and position of methyl radicals substituting the hydrogen atoms of one of the amino groups.

Chromatographic analysis was carried out on a Prominence LC-20 liquid chromatograph with an automatic dispenser and a diode-matrix detector and a $\mathrm{pH}$ meter with a combined glass electrode.

The separation of the products of interaction of the components of gentamicin with OPA in a reversed-phase system was optimized using a mixture of acetonitrile - water - perchloric acid - ammonia as a mobile phase. When optimizing the conditions for the separation of derivatives of gentamicin and OPA, it was shown that the separation of peaks improved when the $\mathrm{pH}$ of the salt component of the mobile phase changed from 2.5 to 6.1 . In addition, a gradient profile that provided the minimum analysis duration with the complete separation of the components was selected.

The effect of the DMSO content on the rate of derivatisation and the stability of the reaction products was studied. It was shown that the content of organic solvent in the range of $20-30$ vol.\% provides the maximum stability of the resulting products.

It was found that the rate of the derivatisation reaction is maximum for the first product eluted, minimum for the last product, and has an intermediate value for components with intermediate retention times. The reaction rate depends on the number of methyl substituents of the amino group and their position, which has a steric effect on the interaction of the components with the reagent. The hydrophobicity of the separated products also depends on these factors, which explains the correlation of the order of elution with the rate of the derivatisation reaction.

The obtained patterns can be used in the development of methods for the analysis of organic substances and their mixtures by HPLC with precolumn derivatisation.

Keywords: gentamicin, drug components, ortho-phthalic aldehyde, derivatisation reaction rate, elution order.

\section{References}

1. European Pharmacopoeia. 8th edition (EP 8.0), 2013, Vol. 2, pp. 2326-2328.

2. The United States Pharmacopoeia. The National Formulary (USP36 - NF31), 2013, Vol. 2, pp. 3720-3721.

3. European Pharmacopoeia Reference Standard. Information Leaflet. Gentamicin for Peak Identification Crs batch 3. 2017, 3 p.
4. Moldoveanu S., David V., J. Chromatography Library, 2002, Vol. 65, pp. 341-401.

5. Abdulsalam I. Al-Amoud, Brian J. Clark, Henry Chrystyn, J. Chromatogr. B, 2002, Vol. 769, pp. 89-95.

6. Cabanes A., Cajal Y., Haro I., Garcia Anton J.M. et al., J. Liq. Chromatogr., 1991, Vol. 14, No 10, pp. 1989-2010.

7. Walker S.E., Coates P-E., J. Chromatogr., 1981, Vol. 223, pp. 131-138. 
8. Larsen N-E., Marinelli E., J. Chromatogr. B, 1980, Vol. 221, pp. 182-187.

9. Win L. Chiou Roger L. Nation Geoffrey W. Peng Shiew-Mei Huang, Clin. Chem, 1978, Vol. 24, No 10, pp. 1846-1847.

10.GOST 31789-2012. Fish, marine invertebrates and products of their processing. Quantitative determination of biogenic amines by high-performance chromatography, M., Standardinform, 2014, $11 \mathrm{p}$.

Голубицкий Григорий Борисович - д.х.н., старший химик-аналитик ООО «Центр фармацевтической аналитики», Москва

Шохин Игорь Евгеньевич - д.фарм.н., генеральный директор ООО «Центр фармацевтической аналитики», Москва

Миненкова Ирина Владимировна - младший научный сотрудник лаборатории физикохимических основ хроматографии и хроматомасс-спектрометрии, Институт физической химии и электрохимии им. А.Н. Фрумкина, Москва

Буряк Алексей Константинович - заведующий лабораторией физико-химических основ хроматографии и хромато-масс-спектрометрии, проф, д.х.н., член-корреспондент РАН, директор ФГБУН Институт физической химии и электрохимии. им. А.Н. Фрумкина, Москва
11.Gyarmati B., Hegyesi N., Pukánszky B., Szilágyi A., Express Polymer Letters, 2015, Vol. 9, No 2, pp 154-164.

12.Barends D. M., Zwaan C. L., Hulshoff A., J. Chromatogr. B, 1981, Vol. 222, pp. 316-323.

13. Golubitsky G.B., Vladimirova E.V., Ostrovsky K.P., Gelperina S.E., Sorptsionnye I khromatograficheskie protsessy, 2017, Vol. 17, No 5, pp. 772-780.

14.Golubitsky G.B., Ostrovsky K.P., Gelperina S.E., Sorptsionnye I khromatograficheskie protsessy, 2018, Vol. 18, No 4, pp. 543-553.

Golubitsky Grigory B. - Senior chemist-analyst of «Center for pharmaceutical Analytics» LLC, doctor of chemical sciences, Moscow, e-mail: g.golubickiy@cpha.ru

Shohin Igor E. - general director of «Center for pharmaceutical Analytics» LLC, doctor of pharmaceutical Sciences. Moscow, e-mail: i.shohin@cpha.ru

Minenkova Irina V. - junior researcher, laboratory of physicochemical principles of chromatography and chromatography - mass spectrometry; Institute of Physical chemistry and electrochemistry, Moscow, irina.vl.minen kova@mail.ru

Buryak Aleksey K. - Director of the Institute of physical chemistry and electrochemistry named after A. N. Frumkin", Corresponding member of the RAS. Moscow, e-mail: akburyak@mail.ru 